Please cite this article as:

Kotzab, Herbert, Grant, David B., Teller, Christoph, Halldorsson, Arni. 2008. Supply Chain Management and Hypercompetition. Logistics Research, 1 (1), pp. 12-20. 


\section{SUPPLY CHAIN MANAGEMENT AND HYPERCOMPETITION}

Herbert Kotzab *)

Department of Operations Management

Copenhagen Business School

DK-2000 Frederiksberg, Denmark

E-mail: hk.om@cbs.dk

David B. Grant

Logistics Institute

University of Hull

Hull, United Kingdom HU6 7RX

E-mail: d.grant@hull.ac.uk

\section{Christoph Teller}

Institute for Retail Studies

University of Stirling

Stirling, United Kingdom FK9 4LA

E-mail: christoph.teller@stir.ac.uk

\section{Arni Halldorsson}

School of Management

University of Southampton

Southampton, United Kingdom SO17 1BJ

E-mail: A.Halldorsson@ @oton.ac.uk

*) corresponding author 


\title{
SUPPLY CHAIN MANAGEMENT AND HYPERCOMPETITION
}

\begin{abstract}
Firms nowadays face significant challenges in their operating environments, which have been characterised in two different ways. From a strategic management perspective these environments are in a state of hypercompetition while from a logistics or supply chain perspective these environments require market responsiveness predicated upon agile supply chains. However, firms must also rely on many interorganizational relationships to ensure efficient and effective movements within their supply chains. This paper discusses the relationships among these concepts and proposes a research framework combining aspects of the hypercompetition and responsiveness and agility viewpoints.
\end{abstract}

\section{Introduction}

Since the early 1990s firms have faced significant challenges in their operating environments, including stagnant or decreasing market volumes, shorter product and technology lifecycles, and more demanding consumers and competition driven by price that forces participants to rationalise resources wherever possible (e.g. human resources or logistics). These environments have been characterised in two different ways.

From a strategic management perspective D'Aveni [7] characterises such environments as being in a state of hypercompetition. Hypercompetition is a condition of rapidly escalating competition based on price-quality positioning and first-mover advantage to either protect or invade established product or geographic markets, and which requires substantial financial resources in the firm and/or alliances with other firms to utilize more substantial financial resources. 
From a logistics or supply chain perspective Christopher [3] characterises such environments as requiring a market responsiveness that calls for the establishment of agile supply chains. Agile supply chains are able to adapt much faster to market changes in terms of product volume and variety to meet customer's needs.

However, supply chain management (SCM) is not restricted solely to a focal firm due to increased globalization and lengthy supply chains. Firms must rely on interorganizational relationships to ensure the efficient and effective movement of products and supplies, money, and information to all relevant parties in the supply chain.

This paper discusses the relationships among these concepts and proposes a research framework combining aspects of D'Aveni's [7] hypercompetition and Christopher's [3] responsiveness and agility viewpoints by positing two questions. Firstly, under what conditions might interorganizational relations and supply chain processes overcome responsiveness and hypercompetitive challenges? Secondly, once these conditions are known how might a firm design and manage its interorganizational relations and supply chain processes in order to survive in such an environment? We first discuss aspects of the turbulent business environment that firms now face.

\section{The Turbulent Business Environment}

Business environments changed dramatically during the 1990s. Stagnant and decreasing market volumes had major impacts on profit margins in various industries during the 1990s. For example, net profit margins of grocery retailers in many countries, excluding the United Kingdom, are in a discouraging range between -0.5 and +1.5 percent [27]. 
The nature of customers and consumers also changed during that time. Changing consumer tastes, increased consumer sophistication, smaller household sizes and the growth of older consumer segments, inter alia, have presented new challenges for manufacturers and retailers [21].

Many industries have also experienced a power shift from manufacturers to retailers, mainly due to the increasing size of several retail players $[6,10]$. Wal-Mart's sales in 2000 of nearly US \$194 billion were about five times higher than Procter \& Gamble's sales of approximately US \$40 billion in the same year [9].

The rate of change has increased dramatically during the last twenty years and has developed increased business 'turbulence' [5]. Five levels of turbulence and their impact on organizations are presented in Table 1. Turbulence levels 4 and 5 are more demanding and require organizational strategies to be more entrepreneurial and creative and to consider restructuring internal and external organizational relationships, particularly supply chain relationships.

\section{Insert Table 1 here}

The increase in the rate of change and thus the concept of time as regards this change, product lifecycles and so on also affects modern businesses and supply chains. Fine introduced the term 'clockspeed' to describe an industry's evolutionary life cycle, which is a function of the speed at which products, processes and organizational structures are introduced [8]. As an industry's clockspeed increases competitive advantage is difficult to sustain. Fine argued that the ultimate source of sustainable competitive advantage is a company's ability to manage its supply chain, i.e. being market responsive in a time-conscious and turbulent environment. 
Table 1 also illustrates an increased complexity in modern business environments, which also has consequences for the management of supply chains. Lewin argued there are parallels with complexity in natural science. Traditional business hierarchies with command and control structures minimize interactions among actors in an organization's environment, which in turn inhibits creativity [22]. Lewin considered management should be guided by complexity science and recognize that relationships are an organization's desired output, from which creativity, culture and productivity emerge. Thus, traditional, linear and mechanistic hierarchies of business are going to be replaced more and more by decentralized and modular networks that are cooperative-oriented, autonomous and indirectly coordinated [22].

Beyond these perspectives of rapid and significant change and 'displacement competition' where a firm can only gain market share by decreasing a competitor's market share, the development of interorganizational relationships and supply chain processes should enable firms to obtain a competitive advantage $[10,11]$. Such an orientation is readily characterized by the concept of supply chain management (SCM); which is recognized as a necessary strategic weapon for ensuring a firm's competitive advantage and is considered a management-driven competency [12]. We next discuss aspects of hypercompetition.

\section{Theory and Aspects of Hypercompetition}

There are two different meanings for hypercompetition. Firstly, the term describes an intensive rivalry and rapidly changing condition in markets or industries. According to D'Aveni this phenomena can be identified in almost every industry from consumer goods to telecommunications [7]. Secondly, it presents a conceptual model for the strategic behavior of firms and interorganizational relationships from a management point of view. In both cases it is necessary to know how to cope with hypercompetition. 
The theory of hypercompetition argues that firms operate in four different competitive 'arenas' within their respective industries [7]:

1. Cost and Quality: a firm can have either a low cost-low quality product or a high cost-high quality product. Over time a low cost producer will increase quality and a high cost producer will decrease prices, thus there will be convergence in the minds of the customer and a possible perception that the product is a commodity.

2. Know-how and Timing: a firm's knowledge base and the timing of product releases can be very important to its success. Procter \& Gamble and IBM are two firms that have used their strong patent portfolios to garner extra revenues of up to a billion dollars a year.

3. Strongholds: these are markets, geographical or product, where a firm is very strong and which provide a source of continuous sales and profits. These almost-proprietary markets provide certain profits and cash flows to allow the firm to attack a competitor in its market.

4. Deep Pockets: here a firm will have a large amount of cash reserves to help it in times of change, introduce new products, enter new product markets and attack competitors.

Having an advantage in all four arenas does not necessarily provide a continuous competitive advantage; they are only temporary sources of advantage in hypercompetitive markets since competitors in every market will also seek to improve the quality of their products, reduce costs and create their own cash reserves through mergers and alliances [7].

We consider the elements of these four arenas fit into two of Johnson and Scholes' generic strategy options, market moves and building barriers, that firms can adopt in order to gain competitive advantage as shown in Table 2 [18].

\section{Inset Table 2 here}


Market moves relate to being market responsive while building barriers relate to establishing nearmonopolistic or oligopolistic market behaviour. The former option fits with Christopher's concept of market responsiveness or agility however the latter option reduces market responsiveness [3]. We next consider aspects of SCM affected by hypercompetition.

\section{SCM and Hypercompetition}

The logistics and SCM literature distinguishes between an institutional level (who performs logistics/SCM) and a functional level (how is logistics/SCM performed). Another characteristic is the application of a systems view, i.e. systems thinking that supports the integration of all activities within a logistics system or supply chain [12]. This means that individual components in such systems should not be treated in isolation since they are inter-related [24]. From an institutional point of view, one can distinguish between micro- and macro-logistics/SCM systems depending on the unit of analysis [17].

Some authors argue that a firm's supply chain functions should be considered as micro-systems [12]. However, we consider these systems are subsystems of macro-systems, such as technological infrastructure (e.g. traffic systems, IT-systems). As micro-systems are also linked to one another (e.g. raw material suppliers, manufacturer, retailer, and third-party logistics providers) there is also the notion of a meta-system that focuses on the coordination of logistics and supply chain systems in different firms. Here, competitive settings such as hypercompetition seem to apply not only to micro-systems but also to meta-systems. Stern et al. (1996) recognized that a marketing channel, or essentially a supply chain, is the result of different environmental intercourse [29].

A change in one environmental factor will consequently change the overall setting, including design and management of a supply chain. This situation has been neglected by many SCM researchers, 
who put more emphasis on discussing SCM from the viewpoint of the supply chain, but not from the competitive background of the supply chain and the individual firm [2, 20].

Further, the formation of long-term relationships is contingent on various interrelationships within the wider environment of the supply chain, especially the nature of competition in a particular industry. Thus, to be market responsive in hypercompetitive environments, a firm can consider using differentiation strategies for existing products/logistics services or markets, being the first mover in a particular market, or introducing new products/logistics services in existing or new markets in order to build competitive advantage. Deeper and more meaningful relationships within the firm's supply chain will be required to do so.

There are two tensions between the value or push chain and demand or pull chain strategic positions that developed during the 1990 s that primarily relate to cost and value respectively. One is the lean production position, which considers value creation from the customer's perspective but focuses on the product and waste that surrounds activities related to the entire production system [16]. The lean position is based on Ohno's work in Japanese automobile manufacturing, and represents an efficiency approach towards logistics or SC activities and encompasses techniques used in just-intime (JIT), total quality management (TQM) and materials resources planning (MRP) environments.

In contrast, the agile position is a flexible approach to logistics or supply chain activities that enables rapid response and change and has its origins in flexible manufacturing systems. It encompasses customer demand and involvement in designing and implementing product manufacturing and supply chains [3, 30]. Empirical examples of agile supply chains are efficient consumer response (ECR) systems in the food supply chain [19]. 
Although theoretical discussions of both lean and agile positions were developed during the last fifteen years, they are not entirely new concepts. Bucklin's theory of channel structure developed in the 1960s is based on two similar concepts: postponement and speculation $[33,12]$. Some authors have attempted to choose and defend either an agile or lean position arguing that the two concepts appear incompatible. The difference between the two positions was succinctly described by Christopher: "agility is needed in less predictable environments where demand is volatile and the requirement for variety is high. Lean works best in high volume, low variety and predictable environments" [3: 39].

Both environmental situations may be present within one supply chain. A classic example is cotton sweaters produced by Benetton [3]. Benetton mass-produces certain styles of sweaters in order to decrease costs of production and they are uncoloured and unprinted. Colour dyeing and printing of the sweaters occurs just before they go to market to take advantage of current fashion trends in individual markets.

This approach combines the benefits of both lean/agile and speculation/postponement strategies and is shown in Figure 1. The decision point where a lean or push strategy changes to an agile or pull strategy has been termed the 'decoupling' point. It is the point or depth in the supply chain where "real demand is made visible... reflects the ongoing requirement in the final market place as close to real-time as possible" and "should also dictate the form in which inventory is held" [3: 41]. Indeed, some authors have considered positions both in a manufacturing setting and termed the resultant position as leagile [23].

\section{Insert Figure 1 here}


The adoption of both lean and agile strategies in one hybrid supply chain and the location of the decoupling point will vary with different product and supply chains [30]. Flow of product up to the decoupling point may be forecast-driven whereas flow of product after the decoupling point should be demand-driven [3].

A hybrid supply chain scenario that allows compatibility of the lean and agile concepts and which suggests strategies of cost reduction and market responsiveness should also be compatible under a hypercompetitive supply chain scenario. Thus, the concept of an agile SC being market responsiveness and demand driven can be combined with market move strategies in a hypercompetitive environment that is time and cost-driven to effectively establish an ongoing competitive advantage, as opposed to a short-term advantage within a solely hypercompetitive context.

We posit the main questions for managers, whose firms operate more and more in responsive and hypercompetitive markets, as:

- What are the conditions under which interorganizational relations and supply chain processes help to overcome responsiveness and hypercompetitive challenges?

- And, when knowing these conditions, how should firm relations and supply chain processes be designed and managed in order to survive in a responsive and hypercompetitive environment?

To address these questions we now introduce a conceptual framework showing the relationship between responsiveness and hypercompetition that extends the domain of the supply chain to a 'meta-level'. This meta-level domain and our framework consider how logistics and supply chain systems are influenced relative to technological, infrastructure, political, social and economic environmental factors. 


\section{Interorganizational Structures and a Framework for Hypercompetition and SCM}

The changing business environment impacts organizational structures. Within a traditional business setting, firms are typically perceived as single, self-contained units with clear and determinate internal and external boundaries, e.g. set by physical location factors or laws [31]. These boundaries have also become more blurred in today's competitive environment as shown in Figure 2.

\section{Insert Figure 2 here}

Traditional hierarchies with their command and control structures are more and more being replaced by decentralized, modular, cooperative-oriented, autonomous and indirectly coordinated networks, in concert with Lewin's suggestions [22]. Such new organizational constructions overcome discrepancies and borders in space, time and behavior faster and better than conventional structures. For the borderless organization, Chandler's rule of 'structure follows strategy' [1] might be better thought of as 'structure follows flexibility and innovation', due to such changing and unstable conditions. Within the grocery industry, Wal-Mart and Procter \& Gamble have already developed a good example of a borderless organization, where internal (functional) and external (organizational) boundaries were set aside [19].

Two predominant theories in economics, strategy and organization are transaction cost economics (TCE) and the resource-based view of the firm (RBV). They apply the notion of the firm as the level of analysis. The body of literature within both marketing and logistics/SCM however seems to verify that the boundaries of the firm are much more blurred than suggested by TCE and RBV. The increasing division of labor in a supply chain governed by a hybrid form of governance mechanism [32] has been recognized as a means of competitiveness through terms such as 'strategic sourcing' 
[26] and 'cooperate to compete' [25]. And yet, we can argue these terms may be considered more commonly as SCM.

The predominant views on SCM relate to the integration of business processes [4] and relationship management [2] in a supply chain to achieve competitive advantage. Although the level of analysis has moved away from the firm towards interorganizational relationships both TCE and RBV [15] and the means of creating and developing resources and capabilities [28] can still be applied to achieve improvement.

The wider context of the supply chain or network, particularly its adaptation in organizing economic activities under the condition of hypercompetition, has yet been not explicitly discussed. All SCM models assume competition as a given - a 'ceteris paribus' presumption. However, as Fine [8] and Dawson [5] both argued firms are set in dynamic environments and change according to their influences, i.e. today's markets are changing rapidly.

Halldorsson et al. argued that SCM itself is not a theory, but should be understood and explained by references to existing theoretical frameworks of economics, strategic management, distribution channels, and organizations [14]. This view considers SCM as an intersection of theories from various disciplines that present strategic implications for particular managers [13]. Table 3 presents some of these theoretical approaches from various disciplines and their consequences for hypercompetition.

\section{Insert Table 3 here}

Hypercompetition adds a new dimension to each theoretical approach. We believe research interest lies both with how hypercompetition constrains a particular theory and how problem solving 
capacity can be enhanced. Research outcomes would include investigating new attributes that not only have theoretical implications, but also generate new opportunities of actions for managers.

The conditions of hypercompetition and market responsiveness help us to question not only how clear but also how stable interorganizational relationships are. TCE directs the focus to the extant nature of interorganizational relationships, i.e. the 'nuts and bolts' or contractual considerations, while RBV directs the focus towards issues such as what competencies are necessary to compete in hypercompetitive markets but more importantly how to prevent erosion of current competencies under these conditions. Also, to what extent is the network organization is a precursor or a hurdle, respectively, for hypercompetitive and responsive markets.

Considering only marketing and logistics, hypercompetitive conditions mobilize focus towards issues where we are not only able to discuss the functional perspective of a supply chain, but also the stability of its functionality and the generative mechanisms for successful relationships. Further, conditions of hypercompetition attack the presumption of the supply chain as an open system by questioning not only the boundaries of the system, but what is more important how to establish interfaces between these particular environmental conditions and the individual supply chain.

Our assumptions are based on a normative model in order to recommend why, when and how to design interorganizational relationship-based management decisions under hypercompetition for strategic management in firms. The theoretical grounding of our research is in theories that reflect upon the boundaries of the firm such as TCE, RBV and a network approach (cf. Table 3).

Figure 3 depicts these theoretical approaches in a proposed hypercompetition and SCM network framework. For the last two decades, much effort has been put into the understanding and explaining industrial markets as a set of interdependent, interorganizational relationships. Our 
framework considers these processes of exchange and adaptation between firms but extends the analysis to include understanding the design and management of interorganizational relationships in a situation of hypercompetition.

\section{Insert Figure 3 here}

We argue that elements of hypercompetition, manifested by their TCE and RBV characteristics, impact a supply chain network containing interorganizational relationships. This impact is across all participants in the network, not just the focal firm, and is thus 'meta-level' in its significance. Therefore, a focal firm should consider the state of hypercompetition across their network in order to effectively design and manage these relationships. That should include consideration of the market move and building barriers elements presented in Table 2. Further, the questions behind such consideration should include, inter alia, the questions exhibited in Table 3 as consequences for hypercompetition from the various perspectives.

As noted in our discussions above his integrative and environmental approach has not seen much investigation in the logistics and supply chain management disciplines. Thus, a research agenda to empirically test this framework should:

(i) determine which elements of hypercompetition in a focal firm's environment are relevant to the firm's network;

(ii) determine whether relevant elements are necessary antecedents to establishing interorganizational relationships with other network participants; and

(iii) examine a focal firm's logistics and supply chain processes to determine how its network can be more responsive in a hypercompetitive situation using lean and agile concepts, particularly decoupling point analysis. 
Both aspects could be investigated at the same time, and we see exploratory research as being a first step to investigate this little-researched phenomena and determine how managers view the impact of hypercompetition and market responsiveness on their firm and environment, the latter including various network stakeholders such as suppliers, customers and competitors. Such exploratory research should take the form of qualitative investigation by interviews, focus groups or case studies.

\section{Conclusions}

The objective of this paper and our proposed research framework has been to extend and complement that part of the SCM literature concerned with strategy and the design and management of interorganizational relationships. We acknowledge that while SCM has to cope with fluctuations in demand (e.g. the bullwhip effect), the interface with the nature of competition or in this case hypercompetition as an environmental condition in a responsive market and a particular supply chain must be made much more explicit.

\section{References}

[1] Chandler, A. (1962) Strategy and Structure. MIT Press, Cambridge.

[2] Christopher, Martin (2005) Logistics and Supply Chain Management: Creating Value-Adding Networks ( $3^{\text {rd }}$ Edn.). FT Prentice Hall, London.

[3] Christopher, Martin (2000) The Agile Supply Chain: Competing in Volatile Markets, Industrial Marketing Management, Vol. 29, pp.37-44.

[4] Cooper, Martha C., Douglas M. Lambert and J. Pagh (1997) Supply chain management: more than a new name for logistics, International Journal of Logistics Management, Vol. 8 No. 1, pp.1-14.

[5] Dawson, John A. (1995) Strategies for retailers in Europe by 2000, In M. Johnson et al. (eds.) Facing up to the Challenges of Retailing, ESOMAR, Amsterdam, pp.191-204.

[6] Dawson, John A. (2000) Viewpoint: retailer power, manufacturer power, competition and some questions of economic analysis, International Journal of Retail \& Distribution Management, Vol. 28 No. 1, pp.5-8.

[7] D’Aveni, Richard (1994) Hypercompetition: Managing the Dynamics of Strategic Maneuvering. The Free Press, New York. 
[8] Fine, Charles (1998), Clockspeed: winning control in the age of temporary advantage. Persues Books, Reading, Massachusetts.

[9] Fortune 500 (2001), Fortune, April 16, Vol. 143 Issue 8.

[10] Kotzab, Herbert and Christoph Teller (2003), Value-adding partnerships and co-opetition models in the grocery industry, International Journal of Physical Distribution \& Logistics Management, Vol. 33, No. 3, pp. 268-281.

[11] Grant, David B. (2005), The Transaction - Relationship Dichotomy in Logistics and Supply Chain Management, Supply Chain Forum: An International Journal, Vol. 6 No. 2, pp.38-48.

[12] Grant, David B., Douglas M. Lambert, James R. Stock and Lisa M. Ellram (2006) Fundamentals of Logistics Management: European Edition, McGraw-Hill, Maidenhead, UK.

[13] Halldorsson, Arni and Paul D. Larson (2000), Wanted SCM! A Search for Elements of SCM in Logistics Education and Research, In Bernard J. La Londe and Terrance L. Pohlen, (Eds.) Redefininglogistics.com: Proceedings of the $29^{\text {th }}$ Transportation and Logistics Educators Conference, pp.216-241.

[14] Halldorsson, Arni, Herbert Kotzab and Tage Skjøtt-Larsen (2003), Interorganizational theories behind supply chain management - discussions and applications, In Stefan Seuring, Martin Müller, Maria Goldbach and Uwe Schneidewind (Eds.) Strategy and Organization in Supply Chains, Physica-Verlag, Heidelberg.

[15] Heide, Jan B. (1994), Interorganizational Governance in Marketing Channels, Journal of Marketing, Vol. 58 (January), pp.71-85.

[16] Hines, Peter, Daniel Jones and Nick Rich (2001), Lean Logistics, In Anne.M. Brewer, K.J. Button and D.A. Hensher (Eds.) Handbook of Logistics and Supply Chain Management, Pergamon, Oxford, pp.171-194.

[17] Ihde, Gösta B. (2001), Transport, Verkehr, Logistik ( $3^{\text {rd }}$ Edn.), Vahlen, München.

[18] Johnson, Gerry and Kevan Scholes (2002), Exploring Corporate Strategy (6 ${ }^{\text {th }}$ Edn.), FT Prentice-Hall, London.

[19] Kotzab, Herbert (1999) Improving supply chain performance by efficient consumer response? A critical comparison of existing ECR approaches, Journal of Business \& Industrial Marketing, Vol. 14 No. 5/6, pp.364-377.

[20] Lambert, Douglas M. and Martha C. Cooper (2000), Issues in Supply Chain Management, Industrial Marketing Management, Vol. 29, pp.65-83.

[21] Leeflang, Peter S.H. and van Raaij, W.Fred (1995), The changing consumer in the European Union: A "meta-analysis", International Journal of Research in Marketing, Vol. 12, pp.373-387.

[22] Lewin, Roger (2001), Complexity: Life at the Edge of Chaos (2 ${ }^{\text {nd }}$ Edn.), Phoenix, London.

[23] Naylor, J. Ben, Mohamed M. Naim and Danny Berry (1999), Leagility: Integrating the lean and agile manufacturing paradigms in the total supply chain, International Journal of Production Economics, Vol. 62, pp.107-118. 
[24] Pfohl, Hans-Christian and H.P. Buse (2000), Inter-organizational logistics systems in flexible production networks: An organizational capabilities perspective, International Journal of Physical Distribution and Logistics Management, Vol. 30 No. 5, pp.388-408.

[25] Preiss, Kenneth, Steven L. Goldman and Roger N. Nagel (1996), Cooperate to Compete, Van Nostrand Reinhold, New York.

[26] Quinn, James Briand and Frederick G. Hilmer (1994), Strategic Outsourcing, Sloan Management Review, Summer, pp.43-55.

[27] Seth, Andrew and Geoffrey Randall (1999), The Grocers: The rise and rise of supermarket chains, Kogan Page, London.

[28] Skjøtt-Larsen, Tage and Arni Halldorsson (2002), Developing Logistics Competencies Through Third Party Logistics Relationships, Conference paper, NOFOMA 2002, Trondheim, Norway.

[29] Stern Louis W., Adel I. El-Ansari and Anne T. Coughlan (1996), Marketing Channels (5 Edn.), Prentice Hall, London.

[30] Van Hoek, Remko I., Alan Harrison and Martin Christopher (2001), Measuring agile capabilities in the supply chain, International Journal of Operations \& Production Management, Vol. 21 No. 1/2, pp.126-147.

[31] Wigand, Rolf, Arnold Picot and Ralf Reichwald (2001), Information, Organization and Management: Expanding Markets and Corporate Boundaries, John Wiley \& Sons Ltd., Chichester.

[32] Williamson, Oliver E. (1996), The Mechanisms of Governance, Oxford University Press, New York.

[33] Gill, L. and Allerheiligen P (1996), Co-operation in channels of distribution: physical distribution leads the way, International Journal of Physical Distribution \& Logistics Management, Vol. 26 No. 5, pp.49-63. 


\begin{tabular}{|c|c|c|c|c|c|}
\hline $\begin{array}{l}\text { Turbulence } \\
\text { Level }\end{array}$ & 1 & 2 & 3 & 4 & 5 \\
\hline $\begin{array}{l}\text { Environmental } \\
\text { Turbulence }\end{array}$ & $\begin{array}{l}\text { Repetitive } \\
\text { Slow }\end{array}$ & $\begin{array}{l}\text { Expanding } \\
\text { Fast incremental }\end{array}$ & $\begin{array}{l}\text { Changing } \\
\text { Predictable } \\
\text { incremental }\end{array}$ & $\begin{array}{l}\text { Discontinuous } \\
\text { Discontinuous } \\
\text { and } \\
\text { unpredictable }\end{array}$ & Surpriseful \\
\hline $\begin{array}{l}\text { Strategic } \\
\text { Aggressiveness }\end{array}$ & $\begin{array}{l}\text { Stable } \\
\text { Based on } \\
\text { precedents }\end{array}$ & $\begin{array}{l}\text { Reactive } \\
\text { Based on } \\
\text { experience } \\
\text { Incremental }\end{array}$ & $\begin{array}{l}\text { Anticipatory } \\
\text { Based on } \\
\text { extrapolation } \\
\text { Incremental }\end{array}$ & $\begin{array}{l}\text { Entrepreneurial } \\
\text { Based on } \\
\text { observable } \\
\text { opportunities }\end{array}$ & $\begin{array}{l}\text { Creative } \\
\text { Based on } \\
\text { creativity } \\
\text { Discontinuous } \\
\text { Novel }\end{array}$ \\
\hline $\begin{array}{l}\text { Organisational } \\
\text { Responsiveness }\end{array}$ & $\begin{array}{l}\text { Stability seeking } \\
\text { Rejects change }\end{array}$ & $\begin{array}{l}\text { Efficiency } \\
\text { driven } \\
\text { Adapts to } \\
\text { change }\end{array}$ & $\begin{array}{l}\text { Market driven } \\
\text { Seeks familiar } \\
\text { change }\end{array}$ & $\begin{array}{l}\text { Environment } \\
\text { driven } \\
\text { Seeks related } \\
\text { change }\end{array}$ & $\begin{array}{l}\text { Environment } \\
\text { creating } \\
\text { Seeks novel } \\
\text { change }\end{array}$ \\
\hline Manager Type & Custodian & Controller & Growth leader & Entrepreneur & Creator \\
\hline Leadership & Political & Rational & Inspirational & Charismatic & Visionary \\
\hline Key Knowledge & Internal politics & $\begin{array}{l}\text { Internal } \\
\text { operations }\end{array}$ & $\begin{array}{l}\text { Historical } \\
\text { markets }\end{array}$ & $\begin{array}{l}\text { Global } \\
\text { environment }\end{array}$ & $\begin{array}{l}\text { Emerging } \\
\text { possibilities }\end{array}$ \\
\hline
\end{tabular}

Table 1: Strategic and Managerial Issues for Environmental Levels of Turbulence [5] 


\begin{tabular}{|l|}
\hline Firms seek competitive advantage through: \\
Market Moves \\
Low Price (Cost) or Differentiation Strategies \\
First-mover Advantage or Timing \\
Developing new products or new markets \\
Building Barriers \\
Resource-based Advantage or Know-how \\
Deep Pockets \\
\end{tabular}

Table 2: Competitive Advantage in Hypercompetitive Situations [18] 


\begin{tabular}{|c|c|c|}
\hline \multicolumn{3}{|c|}{ Economic and Organizational Perspectives versus Hypercompetition } \\
\hline Theoretical approach & “Traditional view" & Consequences for hypercompetition \\
\hline Transaction Cost Economics (TCE) & $\begin{array}{l}\text { Why firms? } \\
\text { - Most efficient boundaries of the firm } \\
\text { - Type of governance structure } \\
\text { - Vertical/horizontal integration }\end{array}$ & $\begin{array}{l}\text { - How static are boundaries of the } \\
\text { firm? } \\
\text { - How unambiguous are the } \\
\text { boundaries of the firm? } \\
\text { - Vertical/horizontal competition }\end{array}$ \\
\hline Resource-Based View (RBV) & $\begin{array}{l}\text { Why do firm differ? } \\
\text { - } \quad \text { Firm heterogeneity } \\
\text { - } \quad \text { Dynamic capabilities }\end{array}$ & $\begin{array}{l}\text { How to develop and preserve core } \\
\text { competencies under hyper- } \\
\text { competition? } \\
\text { What characterizes the core } \\
\text { competence behind the hyper- } \\
\text { competitive firm? }\end{array}$ \\
\hline Network approach (NP) & $\begin{array}{l}\text { - Describing attributes of inter- } \\
\text { organisational relationships } \\
\text { - Development and management of inter- } \\
\text { organisational relationships }\end{array}$ & $\begin{array}{l}\text { - Do networks exist in hyper- } \\
\text { competitive environments? } \\
\text { - Are inter-organisational } \\
\text { relationships to be "developed" ex- } \\
\text { ante, or is their nature much more } \\
\text { "emerging continuously" }\end{array}$ \\
\hline \multicolumn{3}{|c|}{ Logistics/SCM-Perspectives versus Hypercompetition } \\
\hline Theoretical approach & 'Traditional view' & $\begin{array}{c}\text { Consequences for hypercompetition } \\
\text { and SCM }\end{array}$ \\
\hline Marketing Channels Perspective & $\begin{array}{l}\text { - A channel is a set of interdependent } \\
\text { organizations involved in the process of } \\
\text { making a product/service available for use } \\
\text { or consumption. } \\
\text { - Which function has to be performed by } \\
\text { whom in order to make the } \\
\text { product/service available? }\end{array}$ & $\begin{array}{l}\text { - What are the major drivers for a } \\
\text { successful channel setting? } \\
\text { - How stable are these functions? }\end{array}$ \\
\hline Logistics Systems Perspective & $\begin{array}{l}\text { The holistic view on business logistics } \\
\text { helps to overcome institutional and/or } \\
\text { functional barriers in solving logistical } \\
\text { problems. } \\
\text { In such a setting, logistics system are } \\
\text { defined as sets of elements (parts, } \\
\text { components) which are in a relationship } \\
\text { where the elements receive an input (e.g. } \\
\text { costs) and transform this input to an } \\
\text { output (e.g. service). }\end{array}$ & $\begin{array}{l}\text { What are the boundaries of the } \\
\text { systems? } \\
\text { How do we have to set up such } \\
\text { systems under hypercompetition } \\
\text { (question of interfaces?). }\end{array}$ \\
\hline Agile Supply Chains & $\begin{array}{l}\text { - An agile } \mathrm{SC} \text { is flexible in terms of both } \\
\text { manufacturing and logistics activities. } \\
\text { - } \quad \text { An agile } \mathrm{SC} \text { is demand-driven. }\end{array}$ & $\begin{array}{l}\text { - How do we achieve cost reductions } \\
\text { in a flexible SC environment? } \\
\text { - How do we set up and manage a } \\
\text { SC to be responsive to demand and } \\
\text { competition? }\end{array}$ \\
\hline
\end{tabular}

Table 3: Theoretical Approaches versus Hypercompetition [Adapted from 14] 


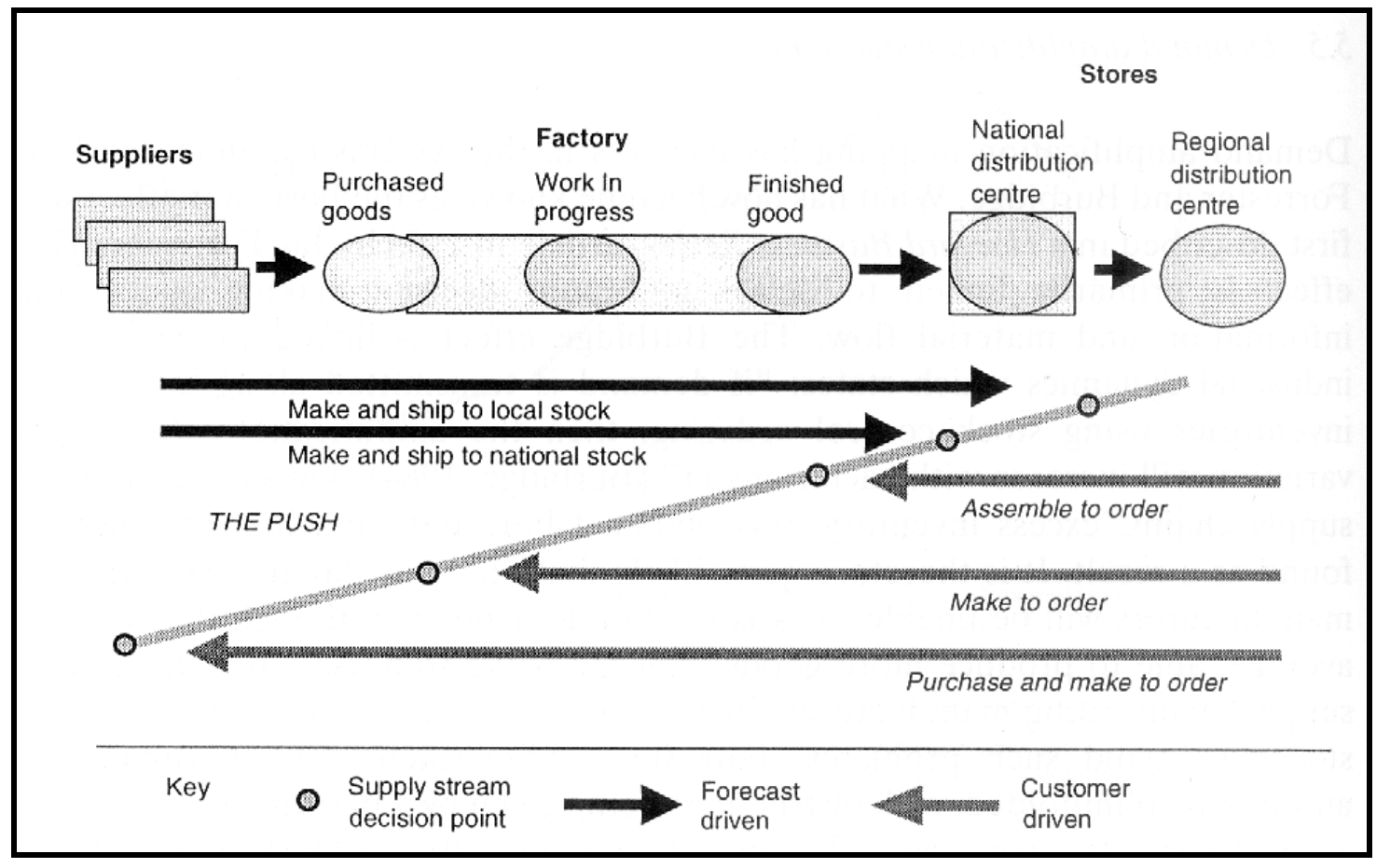

Figure 1: Decoupling Point Analysis - an FMCG example [16] 


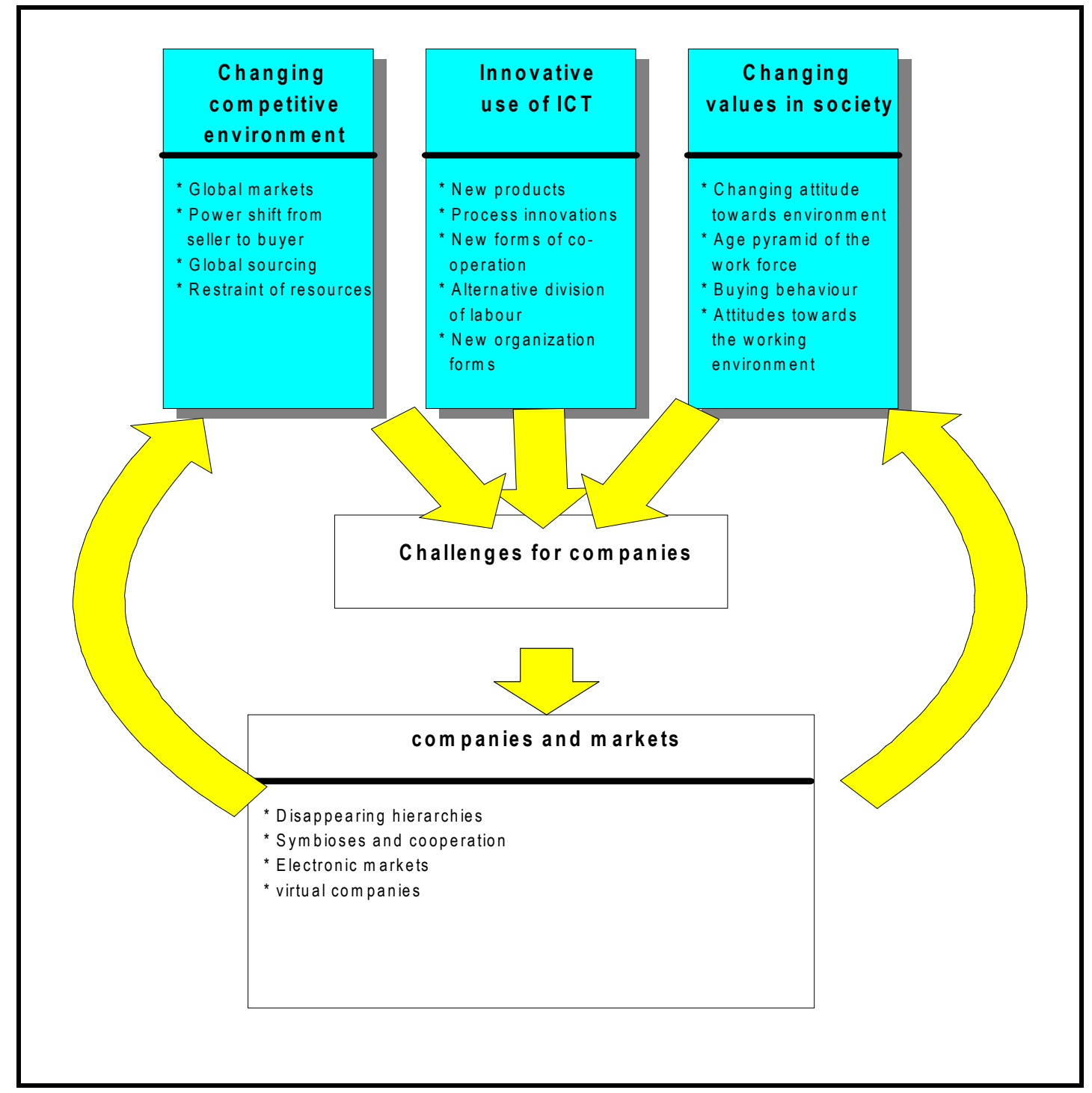

Figure 2: Driving Forces for Changing Firms [31] 


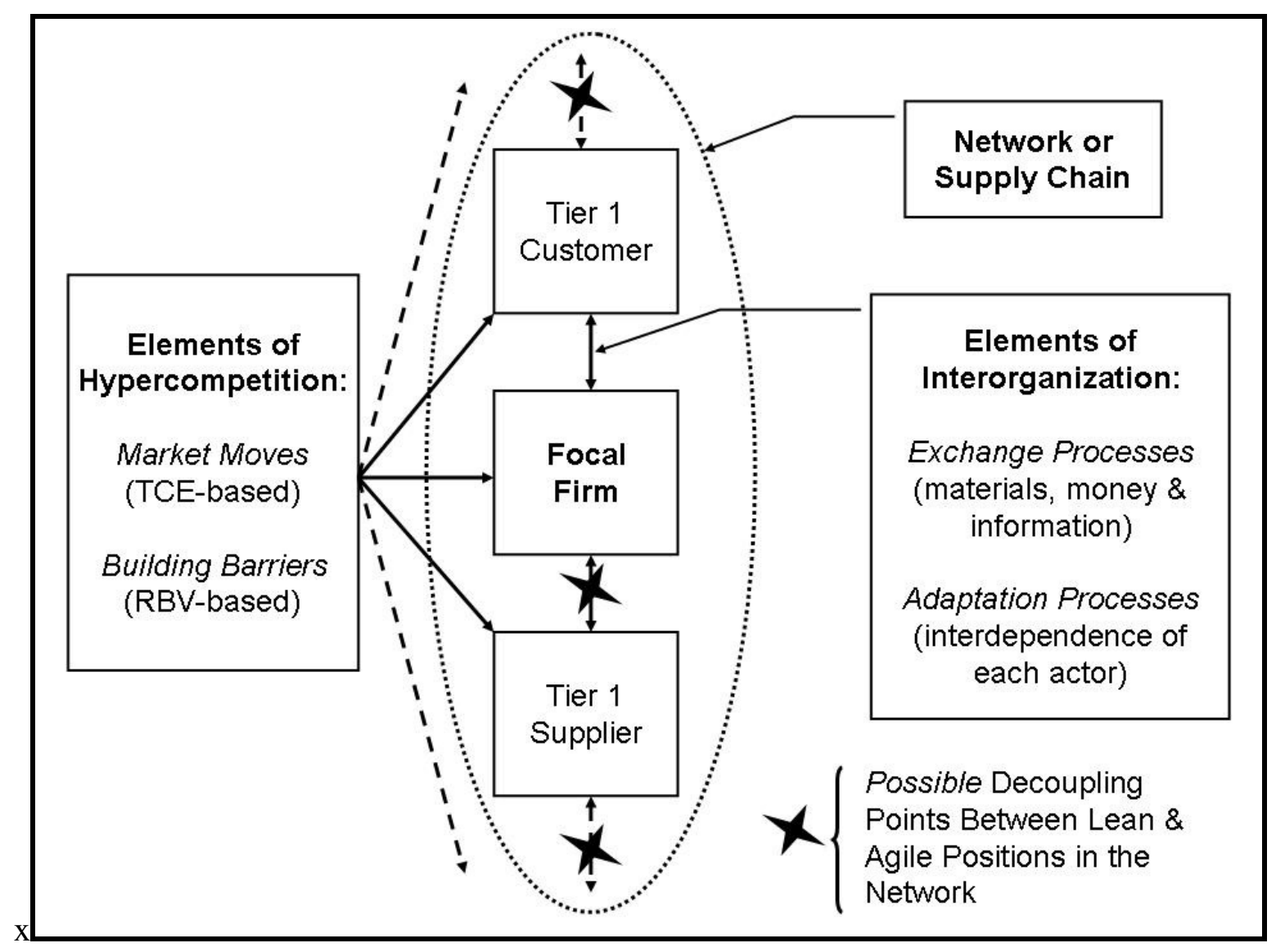

Figure 3: Proposed Hypercompetition and SCM Network Framework 